\title{
Emotion regulation as reflected in children's dreams - a developmental test of the neurocognitive dream theory
}

\author{
PIROSKA SÁNDOR ${ }^{1,2 *}$ - SÁRA SZAKADÁT ${ }^{1}$ - RÓBERT BÓDIZS'1,3 \\ ${ }^{1}$ Institute of Behavioural Sciences, Semmelweis University Budapest, Hungary \\ ${ }^{2}$ Center for Child and Family Welfare, Child Psychology Service, Vecsés, Hungary \\ ${ }^{3}$ Department of General Psychology, Pázmány Péter Catholic University, \\ Budapest, Hungary
}

(Received: 17 November 2015, accepted: 26 April 2016)

Introduction: Although REM sleep plays an important role in neural maturation, developmental aspects of dream research are relatively neglected compared to studies focusing on adults. Adult research found that REM sleep and dreams take certain roles in emotional adaptation, including the processing of emotional events, consolidation of emotional memories and the downregulation of reactions to dysphoric stimuli. These findings, however, are rarely discussed in a developmental perspective.

Aims: We aim to test the neurocognitive dream theory developed by Nielsen and Levine (2007) by investigating the associations among abilities of waking emotional processing, behavioral manifestations of emotional problems and the emotional aspects of dreaming in children.

Methods: We analyzed 349 dream reports of 40 children between the ages of 4 to 8 years. Dream emotions, emotional dream quality and the dreams' effect on daytime's mood were self-reported by the children. Wakeful emotional processing is measured by the Emotional Stroop Test for children, and emotional-behavioral problems were assessed by the parent version of the Strength and Difficulties Questionnaire (SDQ).

Results: Results show that negative dream quality and the dreams' effect on daytime mood are associated with negative emotional adaptation measured by the SDQ $(\tau=.25, \mathrm{p}=.031$, $\tau=.24, p=.041$ respectively). Children with more emotional problems reported more dreams $(\tau=.32, \mathrm{p}=.004)$. Interestingly, we could not find relationship between dream emotions and waking emotional development measures.

Conclusion: Results support psychological models of dreaming assuming a role of dreams in emotional regulation and provide partial support for the plausibility of Levin and Nielsen's neurocognitive theory in a developmental context. Further studies on emotional development and dreaming are needed to gain more insight in the generalizability of the connection between emotional processing during wakeful functioning and REM sleep.

Keywords: dreams, child, emotional development, Emotional Stroop, dream emotions, neurocognitive dream-theory

\footnotetext{
* Corresponding author: Piroska Sándor, Semmelweis University, Institute of Behavioural Sciences, H-1089 Budapest, Hungary, Nagyvárad tér 4. E-mail: sandorpiros@gmail.com
} 


\section{Introduction}

In spite of evidences showing that REM sleep (accompanied by vivid and story-like dreaming in adults) plays an important role in neural maturation and development (Jenni \& Dahl, 2008), developmental dream research is still a relatively neglected field compared to adult investigations. Theories based on dream research studies of adult samples are rarely discussed in a developmental perspective or applied to developmental research, not to mention their deliberate testing on a child population.

Probably the only dream theory primarily based on developmental data is David Foulkes' developmental-cognitive dream theory (Foulkes, 1982, 1985). As content-related and organizational aspects of dreams were shown to mirror the stages of cognitive development as described by Piaget (1976), and the waking correlates of dreaming were mainly cognitive and visuospatial in nature, Foulkes concluded that dreaming reflects the visual constructive abilities of children. In this view dreaming is considered to be merely a gradually developing cognitive achievement showing parallel progression with the developmental stages of the theory of Jean Piaget (1976). Based on a series of longitudinal (Foulkes, 1982, 1999) and cross sectional (Foulkes, Hollifield, Sullivan, Bradley, \& Terry, 1990; Foulkes, Larson, Swanson, \& Rardin, 1969; Weisz \& Foulkes, 1970) studies across a wide age range (3-15 years), Foulkes' results and theoretical conclusions are still prominent reference points in developmental dream research and neuropsychology (Burnham \& Conte, 2010). Although, the dream researchers focusing on the reports of adult volunteers rediscovered and tested the potential relevance and role of dreaming in emotional processing and mood regulation their promising results did not substantially influence developmental research and theories (Sándor, Szakadát, \& Bódizs, 2014). The latter seem to be stagnating in the last decades.

REM sleep has been assumed to take a role in emotional adaptation, including the processing of emotional events, consolidation of emotional memories and the downregulation of reactions to dysphoric stimuli (Cartwright, 2011; Walker \& van der Helm, 2009). Empirical evidence suggests that REM sleep and dreaming may promote the resolution of emotional difficulties and the improvement of next day mood (R. Cartwright, Agargun, Kirkby, \& Friedman, 2006; Yoo, Gujar, Hu, Jolesz, \& Walker, 2007).

Emotions are considered a central feature of dreams appearing in the majority (70-95\%) of adult dreams as self-reported after home and laboratory awakenings with negative emotions appearing more frequently than positive ones (Foulkes, Sullivan, Kerr, \& Brown, 1988; Merritt, Stickgold, Pace-Schott, Williams, \& Hobson, 1994; Nielsen, Deslauriers, \& Baylor, 1991). Emotions in young children's dreams especially at preschool age are 
found be scarce $(8 \%)$ according to laboratory studies, and tend to increase with age (Foulkes, 1982, 1999). Although non-laboratory studies found preschoolers' dreams considerably richer in emotions $(61-80 \%$ of the dreams containing emotions) (Despert, 1949; Honig \& Nealis, 2012; Sándor, Szakadát, Kertész, \& Bódizs, 2015), the tendency of the age-dependent increase is a common finding (Sándor et al., 2015). Thus, in a developmental sense, the process of labelling and verbalizing emotions, especially originating from a different state of consciousness, could be interpreted as a cognitive achievement (Foulkes, 1982; Schachter \& Singer, 1962). This could be of special importance in case of negative emotions when a certain level of emotional processing is necessary before being able to articulate the disturbing affect. Such intolerable affects and an immature emotional regulatory system may cause young children to refuse reporting about dysphoric dreams or nightmares (Despert, 1949).

Presleep affective state modulates dream emotions; stressful life situations often appear together with dysphoric dreams or even nightmares (Schredl, Fricke-Oerkermann, Mitschke, Wiater, \& Lehmkuhl, 2009; Schredl, 2003). There is a growing body of evidence that even specific dream contents have a role in evening to morning mood improvement (Kramer, 1993) and in long term emotional adjustment in a stressful life situation (R. D. Cartwright, 1991).

Earlier findings showed that stress such as interpersonal conflicts and anxiety may be associated with elevated dream recall frequency in adults and in children (Pagel, Vann, \& Altomare, 1995; Schredl \& Montasser, 1996; Schredl, 1999) although results are not homogenous (Brand et al., 2011; Foulkes, 1969). Neuro-anatomical systems of emotional functioning and REM sleep provide an anatomical basis for the above assumptions and empirical results. According to neuro-imaging studies, the medial prefrontal cortex, anterior cingulate cortex, limbic region and basal forebrain together with the occipito-temporal region and visual association cortex are more active in REM sleep than in NREM sleep (Braun, 1997; Maquet et al., 1996). This REM specific activity practically includes the circuits of fronto-limbic emotional network (including amygdala, orbito-frontal cortex and ventromedial prefrontal areas) (Steklis \& Kling, 1985). In awake functioning limbic structures such as amygdale are correlated with emotional responses, especially fear responses (Adolphs, Tranel, Damasio, \& Damasio, 1995; Feinstein, Adolphs, Damasio, \& Tranel, 2011) and the ventromedial prefrontal cortex is involved in emotion regulation and fear extinction processes (Hänsel \& von Känel, 2008; Urry et al., 2006). These results support the hypothesized connection between dreaming and affective experiences, and more specifically the emotional regulational function of dreams (R. Cartwright et al., 1998; R. Cartwright, 2011; Nielsen \& Levin, 2007). The affect network 
dysfunction (AND) model of nightmare production (Levin \& Nielsen, 2007; Nielsen \& Levin, 2007) describes a cooperative system of subcortical and cortical substances in which subcortical areas (such as amygdale) provide the emotional load added to the memory context provided by the hippocampus and cortical areas (such as medial prefrontal cortex and anterior cingulate cortex) are responsible for the regulation of those emotions and the fear-extinction through the dreams. On the cognitive level, fear-extinction operates in dreams similarly to the extinction mechanism of a conditioned response in classical conditioning: repeated associations of the conditioned stimulus (e.g.: a fearful waking - life memory) with new, non-fearful contexts (acquired in dreams) lead to the formation of new memories without the fearful content, which are called fear extinction memories. Fear extinction memories are suggested to be created and maintained during dreaming by three especially dreaming-related processes: 1 ) the activation and availability of dissociated fragments of fear-memories; 2 ) the reorganization of these elements with new contexts; 3 ) modified emotional reaction to these reorganized elements (without the fearful element the emotional reaction changes). According to this neurocognitive theory, emotionally loaded dreams, especially nightmares can be a consequence of a disruption in the cooperation of the emotionally weighted subcortical areas and prefrontal-cortical areas, which are unable to down-regulate those emotions, resulting in an ineffective emotional regulation.

Although the above neurocognitive theory of Levin and Nielsen is aimed at modelling non-functional network behavior resulting in non-typical dreaming (nightmare production), we assume that the functioning of the above described neural network could be traced in typical dreams as well. Several studies point in the direction that waking abilities of emotional functioning may be connected to dreaming and more specifically emotional aspects of dreams (Simor, Pajkossy, Horváth, \& Bódizs, 2012). Thus, in our current study we aim to test the above hypothesis by investigating the associations between abilities of waking emotional processing and behavioral manifestations of socio-emotional adaptation problems with the emotional aspects of dreaming in children. We also assume that by investigating this topic in a developmental context, we might gain more insight in the development of emotional regulation, as well as in the generalizability of the connection between emotional functioning during waking and REM sleep.

\section{Aims and hypotheses}

As a first step we aim to characterize the development of emotional aspects of dreaming, namely positive and negative emotions, emotional dream 
quality and dreams' effect on daytime mood in children between 4 and 8 years of age. Based on the developmental findings of Foulkes, we expect an age-related increase in dream emotions during this period and a similar decrease in the number of dreams affecting daytime mood.

As a second step we conduct a correlational study in order to reveal the associations between the above mentioned dream-related emotional functioning and waking emotional behavior.

Since we expect that with more efficient emotional processing, emotional awareness and accessibility also increases, we therefore expect a positive correlation between the efficiency of emotional processing (measured by the Emotional Stroop Test) and the number of emotions reported in the dream interviews. Based on the neurocognitive theory of Nielsen and Levin we also expect the number of dreams with positive quality to positively associate with the effectiveness of emotional processing. We expect the latter to negatively correlate with the number of dreams affecting daytime mood. This latter expectation is also based on the neurocognitive theory.

Since earlier findings showed an elevated dream recall frequency in association with stress and anxiety, we therefore expect a positive correlation between the emotional-behavioral problems (measured by the Strength and Difficulties Questionnaire, SDQ) and dream recall frequency. Based on the neurocognitive theory of Levine and Nielsen, we expect the total problem score of the SDQ to correlate with the number of negative emotions reported in the dreams together with the ratio of negative quality dreams. We also expect a positive correlation with the number of dreams affecting the daytime mood.

\section{Methods}

\subsection{Participants}

Participants were 40 children and their parents recruited from different schools and kindergartens in Budapest, Hungary, who agreed to take part in the study. We contacted several kindergartens and schools in the city, placed posters about the research and distributed flyers. Finally convenience sampling $^{1}$ and snowball sampling ${ }^{2}$ method turned out to be the most effective way of participant collection in this time and energy demanding study.

\footnotetext{
1 Convenience sampling is a type of non-probability sampling that involves a sample population selected because it is readily available and convenient. Here we used open advertising and accepted volunteers.

2 Snowball sampling is a non-probability sampling technique where existing study subjects recruit future subjects from among their acquaintances.
} 
The children were between the ages of 4 to 8.5 years (min: 3.8, max: 8.7, mean: 6.3 years, SD: 1.6). In order to detect age related differences in dream content we evenly sorted them into 3 age groups: 14 children ( 7 females) between the ages 3.8 and 5.5 years (Group1), 12 children ( 7 females) between the ages of 5.51 and 7 years (Group2), and 14 children ( 7 females) between the age of 7.01 and 8.5 years (Group3).

Children were from a middle class, educated environment with at least one of the parents holding a degree in higher education.

All the children were healthy; any diagnosis of mental or physical illness caused an exclusion from the study. Written consent forms were obtained from the parents. Ethical approval of the study was received from the Semmelweis University Ethical Review Board.

\subsection{Measures and procedure}

\subsubsection{Study procedure}

An initial interview with both the recruited parents and the children was carried out, where they were informed about the details and schedule of the study: children could express willingness to participate and the parents could sign the written consent forms. The parents were trained how to use the structured dream interview developed for this study and how to avoid suggestive questioning and how to obtain the dream reports every morning upon awakening through a 6-week time period.

During the 6 weeks of dream collection period children and their parents visited our laboratory 3 times for the different testing sessions. The first session included the test of intelligence, the second session included the computerized neuropsychological test, including the Emotional Stroop Test for children, and on the third occasion an attachment test took place (results regarding testing other than the Emotional Stroop will be reported elsewhere). Each of these occasions started with a short warm-up game (Hungry hippos) with the researchers to eliminate the possible tensions induced by the environment or the tasks ahead. Each of the testing sessions included optional brakes between the subtasks when children could have a short relaxation, drawing or drinking. After each of the sessions the children were allowed choose a small reward from a present-box in the room. The games, friendly environment continuous reinforcements and little presents kept the children motivated and enthusiastic throughout the study. 


\subsubsection{Methods of dream collection and report control}

Dreams were obtained from the children upon morning awakenings over a 6 week period of time in form of a structured dream interview conducted by the pre-trained parents. The 6 week-period was considered to be long enough to provide a representative sample of the children's dreams. In order to meet the children's possible need for extra attention in the morning we asked the parents to carry out a 5 minute conversation after waking about the night or any other topic that the child showed interest in, even if no dream was recollected. In that way the possible need for attention did not pressure children to make up dream reports.

Interviews were carried out within the first 20 minutes of the waking state each morning and were tape recorded in order to allow retrospective control over the conversation.

In order to rule out parental suggestions and waking fantasy penetrations from entering the reports, we introduced a 3 step control system on the dream collection and evaluation process which included control of the child's narrative by the parent and the researcher, and control of parental influence by the researcher. The steps are:

1. The parents were asked to rate the dream reports on a $0-10$ scale in order to estimate the extent to which the report is a dream (10) or a product of waking fantasy (0). Dreams rated below 5 points were excluded from the research. Parents were also encouraged to name a point (if recognized) where the dream becomes a fantasy, and thus we were able to exclude the products of waking fantasy from the analysis.

2. A research assistant, blind to the parent's ratings, rated the dreams independently on a similar scale using the guidelines of Colace (Colace, 1998, 2010) on dream report credibility. Those dreams, where the two ratings diverged significantly, were excluded from the analysis.

3. Answers to suggestive questions were eliminated from the dream narrative: mentioning any concrete character or event in the parent's question that the child had not mentioned before were considered suggestive (for example: "Was your father there in the dream?" instead of the general "Was there anyone else in your dream?" or "Did anything happen in your dream?").

\subsubsection{Measures of dream content}

After the 6 weeks of data collection, assistants, blind to the purpose of the study, typed the conversations into written documents. During the wordcount process two independent researchers counted relevant words of the dream reports based on the word-count rules described by Foulkes and Shepherd (Foulkes \& Shepherd, 1971). 
In this article we focus on the emotional aspects of children's dreams based on three measures of affective content and effect of the dream reports self-reported by the children:

1. Dream emotions: the children were asked if they had any feelings during the dream and they were given examples of feelings by the interviewer. ("Did you have any feelings during the dream? Did you feel for example angry, sad, happy, surprised or scared or were just calm?"). Positive emotions were happy, good (sometimes they just spontaneously said they felt good) and calm. Negative emotions were sad, scared, angry and bad. (Variables: emotions per dreams, the percentage of dreams with emotions and the ratio of specific emotions compared to all emotions.)

2. Emotional dream quality: is also based on the children's self-report. ("How was this dream? Was it good, bad or neutral?"). (Variable: the ratio of dreams with positive / negative quality.)

3. Effect on daytime mood: based on the self-report of the children dreams were categorized to have an emotional effect on the mood after awakening or not. ("Do you still feel all of these feelings of your dream or did they go away as you woke up?"). (Variable: the percentage of dreams with a reported effect on daytime mood compared to those dream report that contained mood data at all.)

\subsubsection{Measures of emotional functioning}

The Emotional Stroop Test for children (Eschenbeck, Kohlmann, HeimDreger, Koller D., \& Leser, 2004) was used to measure attentional bias and emotional interference control caused by emotionally salient stimuli (MacLeod, Mathews, \& Tata, 1986), a dimension of executive functioning in a situation of emotionally distracting environment.

The task involves the presentation of neutral and emotionally loaded stimuli with different colors, and participants are asked to press the button corresponding to the color of the stimulus as quickly as possible. Since the only relevant stimulus in this task is the color information, subjects have to suppress other perceptual information about the face shown. The shift of attention and the regulation of evoked emotions might demand extra cognitive effort from the subjects, thus causing a slowdown in reaction time as a result of emotional stimuli especially for subjects with emotional processing difficulties (eg. anxiety) (Eschenbeck et al., 2004). In addition, it has been shown that in child studies, unlike in adult studies, the error rates as well as reaction times could be predictive of emotional disturbances, such as nonclinical anxiety (Eschenbeck et al., 2004). Brain imaging studies indicate that the Emotional Stroop task is associated with enhanced activation in the 
amygdala and the anterior cingulate cortex (Bremner et al., 2004; Etkin, Egner, Peraza, Kandel, \& Hirsch, 2006; Whalen et al., 1998). Maintaining attentional set in the presence of salient distractors is attributed to the dorsolateral frontal lobe activity (Compton et al., 2003).

We used a computerized version of the Emotional Stroop Test appearing on a 15-inch monitored laptop computer with colored arrow buttons in the right hand corner. A session of the test included a familiarization phase with the colors (with 4 colored squares as stimuli), a trial phase with the 4 colored schematic faces and neutral facial expression. In the present study Emotional stroop and Fruit stroop were combined, thus the four experimental blocks of stimuli of the test phase contained alternating blocks of Fruit and Emotional stimuli (2 blocks of each). The two blocks of emotional stroop contained 16 happy faces and 16 angry faces (4 types of angry and happy faces in the 4 colors) in a fixed random order.

We used a block design for the stroop task in order to account for the slow effect of the negative emotional stimuli (McKenna \& Sharma, 2004).

Emotional Interference Index (EII), a measure based on reaction times, was calculated by subtracting the average reaction times of happy faces from that of the angry faces. Overall, the bigger the difference is between the two kinds of stimuli, the slower the processing of negative emotional stimuli is. The accuracy measures were recorded and used parallelly.

The Strengths and difficulties questionnaire (SDQ, R Goodman, 2001) is a short 25-question questionnaire completed by the parents, suitable for screening childhood behavioral problems and emotional coping. The Hungarian version was adapted and validated finding an acceptable internal consistency amongst the scales (Cronbach's $\alpha=.68$, Birkás, Lakatos, Tóth, \& Gervai, 2008). Both the original English version and the Hungarian version used in this study show a good correlation with the corresponding scales of the Child Behavior Checklist (Birkás et al., 2008; Goodman \& Scott, 1999). The questionnaire consists of 5 scales each containing 5 items: 1) emotional symptoms, 2) conduct problems, 3) hyperactivity/inattention, 4) peer relationship problems, 5) prosocial behavior. The first 4 is used to calculate the total problem score while the fifth is a positive index for social coping. Each item can be rated in 3 ways: "not true" $(=0)$, "somewhat true" $(=1)$, "definitely true" (=2). The sum of the values of the individual items forms the scale values thus ranging from $0-10$. The sum of the 4 problem scales form the total difficulty scores and the positive scale of prosocial behavior represents the extent to which the child, in spite of the difficulties, is still able to maintain positive behavior with others.

Since here we are particularly interested in emotional development, together with the total problem score of SDQ, we also included emotional problems scale. 


\subsubsection{Data analysis}

Since the number of observations (dreams) per child varied greatly across the sample, dream content characteristics were relativized (average item/ dream) for each child. These were the units of the statistical analyses.

To analyze sample characteristics, analysis was performed by calculating the Kendall tau rank correlation coefficient and using the Mann-Whitney $\mathrm{U}$ test. Since the dream related variables did not meet the conditions for parametric testing, we used non-parametric statistics through the main data analysis sections.

Between-group comparisons testing for the age-dependency of dream report features in children's dream content were performed with the KruskalWallis test, and the Mann-Whitney $U$ test serving as post hoc testing. To explore the correlations between the dream characteristics of the children and their emotional abilities, the Kendall tau ( $\tau$ ) method was used. Age was held constant in all of the correlations.

\section{Results}

\subsection{Description of the data}

Descriptive statistics and gender differences of SDQ and Emotional Stroop Test are given in Table 1. Significant gender differences in the Emotional Interference Index of the Emotional Stroop Test $(\mathrm{U}=110, \mathrm{p}=.014, \mathrm{r}=.38)$ indicated that girls reacted faster to emotionally disturbing stimuli than boys.

Table 1 Mean scores on tests of Emotional Stroop and Strength and Difficulties Questionnaire (SDQ) broken down by gender. Gender differences were analyzed using the Mann-Whitney U test. Degrees of freedom are 38. * $\mathrm{p} \leq .05$.

\begin{tabular}{|l|c|c|c|c|}
\hline & Total & Females & Males & $\begin{array}{c}\text { Mann- } \\
\text { Whitney } \\
\text { U test }\end{array}$ \\
\cline { 2 - 5 } & \multicolumn{3}{|c|}{ Mean scores (SD) } & $* \leq .05$ (df = 38) \\
\hline Emotional STROOP & $0.80(0.17)$ & $0.79(0.18)$ & $0.81(0.16)$ & 188 \\
\hline Emotional Interference Index & $-24.0(86.3)$ & $-48.5(95.5)$ & $3.2(67.1)$ & $110^{*}$ \\
\hline Accuracy in angry faces & 0.80 & 216 \\
\hline SDQ & $7.55(4.8)$ & $8.19(5.6)$ & $6.84(3.7)$ & 258 \\
\hline Total score & $1.73(1.8)$ & $2.14(1.9)$ & $1.26(1.6)$ & \\
\hline Emotional problems &
\end{tabular}


Since measures of emotional processing and emotional problems could covary, we analyzed the possible relationships between the tests and scales used amongst our sample of children (see Table 2). The total score on SDQ is positively related to its subscale, assessing emotional problems $(\tau=.40$, $\mathrm{p}=.001, \mathrm{df}=38$ ). Moreover, total SDQ problem score is negatively related to accurate performance in the Emotional Stroop with distracting negative emotional stimuli $(\tau=-.23, \mathrm{p}=.498, \mathrm{df}=38)$. The Emotional Interference Index (EII) of the Emotional Stroop is characterized by a tendency for a negative correlation with the emotional problem scale of the SDQ $(\tau=-.20$, $\mathrm{p}=.095, \mathrm{df}=38)$. Since the reaction time scale of the EII is reversed, this means a better emotional processing in case of more emotional problems displayed. This relationship could be important when interpreting the correlational results below.

Table 2 Intercorrelations between measures of Emotional Stroop and Strength and Difficulties Questionnaire (SDQ) data. Correlations with age are noted as well. Kendall tau correlations were used for the analysis.

Degrees of freedom are 38. ${ }^{+} \mathrm{p}<10 ;{ }^{*} \mathrm{p} \leq .05 ;{ }^{* *} \mathrm{p} \leq .01,{ }^{* * *} \mathrm{p}<.001$.

\begin{tabular}{|c|c|c|c|c|c|}
\hline & \multicolumn{2}{|c|}{ SDQ } & \multicolumn{2}{|c|}{ Emotional Stroop } \\
\hline & & $\begin{array}{l}\text { Total } \\
\text { score }\end{array}$ & $\begin{array}{l}\text { Emotional } \\
\text { problems }\end{array}$ & $\begin{array}{c}\text { Emotional } \\
\text { Interference } \\
\text { Index }\end{array}$ & $\begin{array}{c}\text { Accuracy } \\
\text { of angry } \\
\text { stimuli }\end{array}$ \\
\hline \multirow[t]{2}{*}{ SDQ } & Total score & & $.40^{* *}$ & -.11 & $-.23^{*}$ \\
\hline & $\begin{array}{l}\text { Emotional } \\
\text { problems }\end{array}$ & & & $-.20^{+}$ & -.04 \\
\hline \multirow[t]{3}{*}{$\begin{array}{l}\text { Emotional } \\
\text { Stroop }\end{array}$} & $\begin{array}{l}\text { Emotional } \\
\text { Interference Index }\end{array}$ & & & & .05 \\
\hline & $\begin{array}{l}\text { Accuracy of angry } \\
\text { stimuli }\end{array}$ & & & & \\
\hline & Age & -.03 & .13 & .13 & $.47^{* * *}$ \\
\hline
\end{tabular}

4.2. Descriptive analysis of the dream variables

The number of dreams reported varied greatly across the sample, with an overall mean of 8.7 dreams per child (sd: 6.3, ranging from 1 to 25 dreams per child). We did not find any significant changes in the dream report rate throughout the age groups (details and more analyses are available at Sándor, Szakadát, Kertész, \& Bódizs, 2015). 
As we have already reported in our previous paper (Sándor, Szakadát, Kertész, \& Bódizs, 2015), the questions regarding dream emotions were not explicitly asked by all the parents. Regarding dream emotions, we only analyze those children's dreams whose parents reliably asked this interview question $(n=33)$. These children's mean age by age-group does not differ significantly from the original sample.

The overall frequency of emotions appearing in dream reports is 0.85 , which means almost one emotion per dream on average and these emotions appear in $64 \%$ of the dreams (Sándor et al., 2015). Neither the frequency of positive ( 0.38 per dream) nor that of the negative emotions ( 0.42 per dream) show significant changes with age (Figure 1).

\section{Emotions per dream}

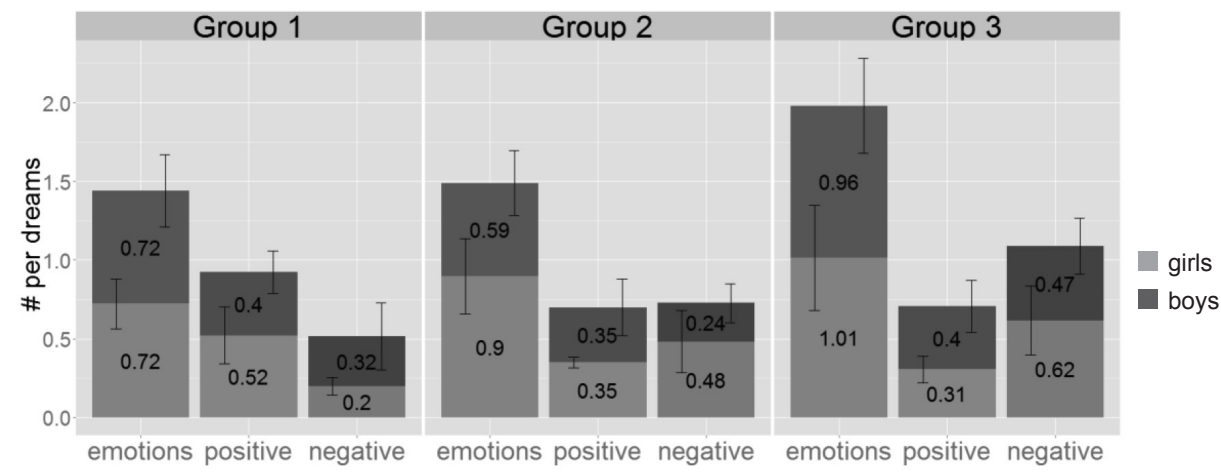

Figure 1 Average number of positive, negative and all emotions per dream by age groups. There is no significant change between the age groups, although we see a tendency of increase of emotions in general and more specifically negative emotions reported per dream with age. Vertical whiskers indicate standard error. Group 1: 3.8-5.5 years, Group 2: 5.51-7 years, Group 3: 7.01-8.5 years.

Similarly to dream emotions, affective dream quality did not show significant changes with age (for details, see: Sándor et al., 2015).

Children reported that $51 \%$ of their dreams had an effect on their daytime mood as assessed in the morning during the dream interview. Unfortunately effect on daytime mood was not evenly assessed by the parents, thus the above percentage was calculated relative to the sum of those dreams that included any data on daytime mood $(173,50 \%$ of all reported 
dreams). The percentage of dream reports with daytime mood assessed varied greatly between the groups with significant differences between G1 $(34 \%)$ and $\mathrm{G} 3(65 \%)(\mathrm{U}=145, \mathrm{p}=.008, \mathrm{r}=.42)$.

The dream's effect on daytime mood is relatively stable except of a sudden drop from group 1 to 2 that only reaches significance in case of the girls (drop from $79 \%$ to $44 \%, \mathrm{U}=55.5, \mathrm{p}=.050, \mathrm{r}=.43, \mathrm{df}=11$ ). There is also a tendency for girls to report more dreams that affect their daytime mood than boys $(\mathrm{U}=224, \mathrm{p}=.096, \mathrm{r}=.27, \mathrm{df}=38$, Figure 2$)$.

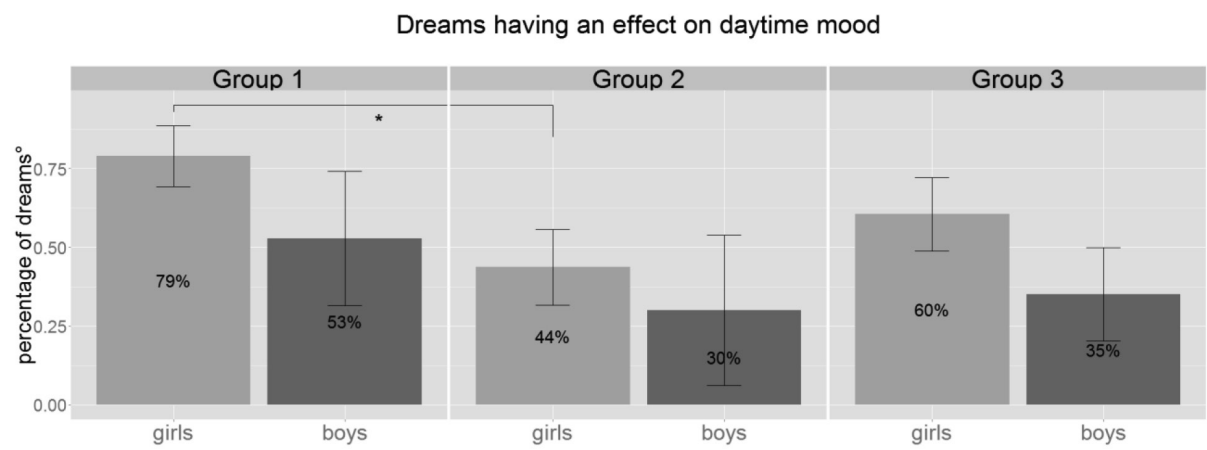

Figure 2 Percentage of dreams that had an effect on the children's daytime mood as reported on the morning of the dream interview relative to the sum of those dreams that included any data on daytime mood.

Dreams affecting daytime mood show a visual decrease from G1 to G2 but only reaches significance in case of girls.

${ }^{\circ}=$ percentage of those dreams that included data on daytime mood, $*=p<.05$, Group1: 3.8-5.5 years, Group 2: 5.51-7 years, Group 3: 7.01-8.5 years.

Correlational analysis between emotional aspects of dreams and waking measures of emotional processing and coping

Interestingly the effectiveness of emotional processing in children in the present sample correlated neither with dream recall frequency nor with emotions in the dreams or emotional quality of the dreams (for more details: Table 3).

However, children with more reported dreams exerting an effect on their daytime mood showed a more efficient control of emotional interference measured by the Emotional Interference Index of the Stroop test $(\tau=-.33$, $\mathrm{p}=.004, \mathrm{df}=35$, Figure 3). 
Table 3 Kendall tau correlation coefficients between dream recall frequency, emotional aspects of dream and waking emotional functioning measured by the

Emotional Stroop Test and the Strength and Difficulties Questionnaire (SDQ).

\begin{tabular}{|c|c|c|c|c|c|}
\hline & & \multicolumn{2}{|c|}{ Emotional stroop } & \multicolumn{2}{|c|}{ SDQ } \\
\hline & & $\begin{array}{l}\text { Emotional } \\
\text { Interference } \\
\text { Index }\end{array}$ & $\begin{array}{c}\text { Accuracy } \\
\text { of angry } \\
\text { stimuli }\end{array}$ & $\begin{array}{l}\text { Total } \\
\text { score }\end{array}$ & $\begin{array}{l}\text { Emotional } \\
\text { problems }\end{array}$ \\
\hline \multicolumn{6}{|c|}{ Kendall-т with $+\mathrm{p}<.1 ;{ }^{*} \mathrm{p} \leq .05 ;{ }^{* *} \mathrm{p} \leq .01$} \\
\hline recall & Dream recall frequency & -.11 & .05 & .11 & $.32 * *$ \\
\hline \multirow[t]{3}{*}{ emotion } & Emotions per dreams & .06 & .04 & -.01 & .06 \\
\hline & Positive emotions & -.02 & .01 & .09 & .03 \\
\hline & Negative emotions & -.00 & .01 & -.01 & .08 \\
\hline \multirow[t]{2}{*}{ quality } & Positive dream quality & -.06 & -.02 & -.01 & -.11 \\
\hline & Negative dream quality & -.09 & .10 & 0.02 & $.24^{*}$ \\
\hline affect & $\begin{array}{l}\text { Dreams affecting } \\
\text { daytime mood }\end{array}$ & $-.33^{* *}$ & -.07 & $.25^{*}$ & $.23^{+}$ \\
\hline
\end{tabular}

Children exhibiting high total behavioral problem scores on the SDQ, more often had dreams affecting their daytime $\operatorname{mood}(\tau=.25, \mathrm{p}=.031$, $\mathrm{df}=35$, Figure 3).

Amongst the scales of the SDQ we analyzed emotional difficulties, that showed a significant positive association the frequency of dream reports $(\tau=.32, p=.004, \mathrm{df}=38$, Figure 3$)$. This means that children exhibiting more difficulties with emotional coping would recall more dreams. Children with more emotional problems also reported more dreams with negative quality $(\tau=.24, \mathrm{p}=.041, \mathrm{df}=36$, Figure 3$)$.

\section{Discussion}

5.1. Descriptive analysis of emotional aspects of dream reports

A descriptive analysis of the number of emotions appearing in the dream narrative (Sándor et al., 2015) reported that emotions are already present in the dreams of preschoolers ( 0.72 per dream). Moreover the average number of emotions per dream in Group 3 (0.99) was comparable to adult standards (1.18; Hall \& Van de Castle, 1966). Here, we extended the investigation with the break-down of dream emotions to positive and negative subcategories. Although these emotional subcategories do not show a significant change 

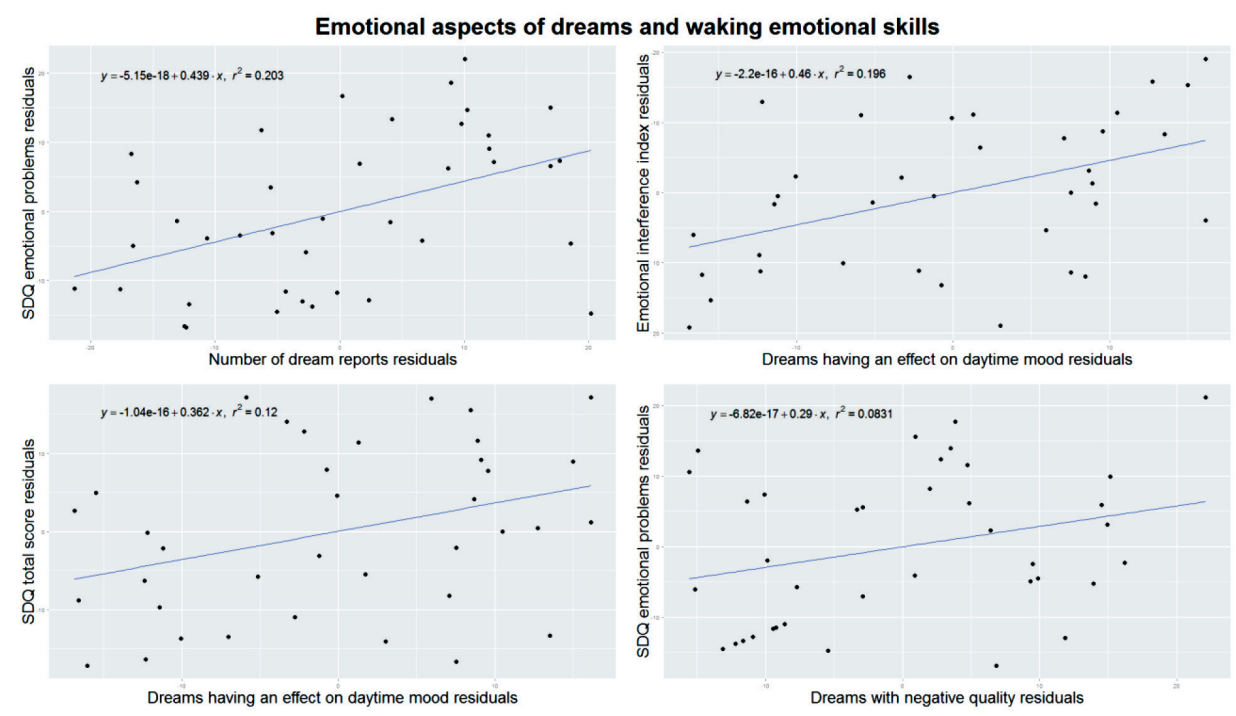

Figure 3 Emotional characteristics of dream reports versus behavioral manifestations of emotional processing skills measured by the Emotional Interference Index of the Emotional Stroop Test and emotional problems measured by the Strengths and Difficulties Questionnaire (SDQ).

All plots are controlled for age by running linear regressions with $x$ and $y$ variables as dependent and age as independent variable and plotting the residuals from both regressions against each other.

Upper left: the average number of dreams recalled is positively correlated with emotional problems measured by the SDQ. Upper right: the ratio of dreams that reportedly affected the next day's mood correlated with emotional processing skills measured by the EII. Lower left: the ratio of dreams that reportedly affected the next day's mood positively correlated with the total problem score of the SDQ. Lower right: the ratio of dreams with negative quality correlated with emotional problem score of the SDQ.

with age, negative feelings in the dreams follow an increasing tendency, similarly to dreams with negative quality. With self-reported emotions by children, questions may rise about the reliability of such reports. Although we have evidence that even preschoolers are able to choose the appropriate affect to a particular narrative (Camras \& Allison, 1985), it is still possible that these reports of matching emotions are motivated by assumed parental expectations and/or are results of waking interpretation. This latter possibility is also present in case of adults' dream reports since results from selfratings seem to differ significantly from those of blind judges (Kahn, PaceSchott, \& Hobson, 2002; Merritt et al., 1994). At this point we have no available information on any comparison between emotions in children's dreams 
rated by the children themselves and blind judges, but according to the present data self-ratings of dream emotions of children and adults are reasonably similar. In fact self-reported positive and negative emotions in the dreams correlated positively with the according dream quality (Sándor et al., 2015), which shows at least a consistency inside the dream narratives.

Based on the self-report of the children we found the majority of the dreams to be positively toned (59\%), with preschoolers having the highest rate of positive dreams (72\%, Sándor et al., 2015). As a comparison, in the school-based research of Honig \& Nealis (2012), they found fewer of preschoolers' dreams to be positive (41.8\%), approximately the same ratio of dreams to be negative ( $21.4 \%$ versus $24 \%$ in our study), and $23.7 \%$ to be neutral. In our study the high proportion of positively rated dreams in preschoolers (72\%, which then drops to $47 \%$ in the oldest age group) and also the practical absence of neutrally rated dreams in the youngest group (4\%) seem to refer to a more simplistic world view described by less differentiated semantic categories in case of preschoolers (Bauer, 1976).

The ratio of dreams affecting daytime mood is highest in the youngest age group (66\%). This might reflect the immaturity of emotional processing abilities of young children responsible for modulating the emotional effect of their dreams in waking life.

\subsection{Correlational analysis between emotional aspects of dreams and waking measures of emotional processing and coping}

Here we found the ratio of dreams affecting daytime mood to be positively associated with effective emotional processing. This means that children whose dreams affected their daytime mood were able to react to stimuli of negative affect in a very effective way, thus we assume that they also processed the presented negative emotions efficiently. This is an unexpected result, since our original assumption about dreams affecting daytime mood was that this characteristic might be a sign of less effective emotional regulation, in a way that negative affects in dreams are still able to influence waking emotional status. Although our original assumption is supported by the finding that the item "dreams affecting daytime mood" (in the Dream Quality Questionnaire) loads positively on the factor "negative emotional load" of adults' dreams (Bódizs, Simor, Csóka, Bérdi, \& Kopp, 2008), the present finding with children seem to contradict the generalizability of this thesis. A previous study (Punamäki, 1999) provides further basis for our original assumption, where authors explored how dream content affected morning mood amongst children living under traumatizing environmental conditions, compared to controls. They found that the dreams' effect 
on the children's daytime mood was stronger and more general in the traumatized group (in both positive and negative ways) than the control group. Unfortunately, they did not report data regarding the emotional coping skills of the children, but being traumatized in itself suggests a challenge, or possibly damage, for the emotional coping system.

Interestingly, those children, who reported more dreams affecting their daytime mood, and who previously were shown to be more effective in the processing of negative emotions measured by the Emotional Stroop Test, also tended to exhibit more emotional-behavioral problems reported by the parents. The resolution of this apparently conflictual finding on dreams affecting daytime mood may lie in the inconsistency of the slowdown in reaction time caused by emotional stimuli in the Emotional Stroop Test (Eschenbeck et al., 2004; Heim-Dreger, Kohlmann, Eschenbeck, \& Burkhardt, 2006; Kindt, Bierman, \& Brosschot, 1997). Some studies even reported the opposite: the decrease of reaction time when faced with emotional stimuli (Hadwin, Donnelly, Richards, French, \& Patel, 2009). One possible explanation for this inconsistency, provided by Heim-Dreger et al. (2006), is that subjects, whose avoidance in connection with the emotional stimuli is stronger than their disturbance by them, may react faster. Thus, it is possible, that the emotional effect of dreams on daytime mood is (as shown in the correlation with parental report) a sign of emotional vulnerability and emotionally vulnerable children in this case tend to avoid negatively toned stimuli. This assumption is supported by the fact that in the present sample the emotional problem score of the SDQ showed a negative correlation with EII results (of the Emotional Stroop Test, see Table 2), meaning that the more emotional problems the children exhibit, the more effective their emotional processing is; another contradiction to which the above hypothesis provides a plausible explanation. Moreover, we found no significant difference between the accuracy measures of the neutral and the emotionally disturbing stimuli, meaning that even if reaction times improved in the negative stimuli group with less effective emotional regulation, accuracy remained unchanged.

These results suggest that the effects of dream emotions on daytime mood could be important indicators of emotional regulatory capacities, but more research is definitely needed to clarify the connection between the two phenomena.

Emotional symptoms measured by the SDQ correlated significantly with dream recall frequency of the children during the 6 week-dream collection period. Earlier findings showed that stress such as interpersonal conflicts and anxiety may be associated with elevated dream recall frequency in adults and in children (Pagel, Vann, \& Altomare, 1995; Schredl \& Montasser, 1996; Schredl, 1999) although results are somewhat inconsistent (Brand et al., 2011; Foulkes, 1969). Our current findings may support the 
salience hypothesis, since according to numerous studies stress increases the emotional intensity of the dreams (for example: Cohen, 1974, Hartmann, 2010). Nevertheless, we cannot exclude other explanations. For example it is plausible to assume that stress increases the occurrence of nocturnal awakenings and therefore dream recall frequency increases (Schredl, Schafer, Weber, \& Heuser, 1998; Schredl, 1999).

Children exhibiting more emotional problems on the SDQ also reported more dreams with negative emotional quality. This finding parallels previous results regarding adults (Michael Schredl \& Engelhardt, 2001) and children (Foulkes et al., 1969; Punamäki, Ali, Ismahil, \& Nuutinen, 2005; Schredl \& Sartorius, 2010). The above convergence suggests that waking life emotional difficulties and struggles leave their impression on human cognitive activity during sleeping and thus are reflected in our dreams. In other words, those children, who are less able to cope with their emotional challenges will finally exhibit more (negatively) emotionally loaded dreams, which might reflect the ineffectiveness of cortical regulation on the emotional load during dreaming and thus supports the neurocognitive dream theory. On the other hand, we did not find a direct correlation between wakeful emotional processing and emotions in the dreams (which could have provided the cognitive-behavioral correlate of the anatomical similarities found in waking emotional regulation and dreaming). These non-consistent results show the need of further research in this area.

In an earlier review we suggested that the supposed fear-extinction and emotion regulation role of dreaming and REM sleep, proposed by the neurocognitive theory of Levin and Nielsen (Levin \& Nielsen, 2007; Nielsen \& Levin, 2007), could be a plausible model for developmental aspects of dreams as well. The AND model assumes the ineffectiveness of the ventromedial prefrontal, as well as dorsal and rostral anterior cingulated cortices in dampening the strong affective reactions induced by the amygdale and thus the lack of fear extinction is leading to nightmare experiences. Nightmares result from affect load (caused by acute stress) and affect distress (dispositional negative affectivity). The same mechanism may function during development, given that the linkage between negative dream quality and daytime emotional problems is present in children as well. Similarly to adults, correlations between emotional disturbances, trauma, and nightmare frequency are also present in children, moreover there are studies showing that children exhibit even more frequent nightmares than adults (Levin \& Nielsen, 2007). This phenomenon could result from the late maturation of the frontal cortex during development, being therefore still ineffective or immature in childhood, so that its tasks in carrying out the regulation of intense emotions arriving from the subcortical areas are affected too. 


\section{Main findings}

Descriptive study

- The ratio of dreams affecting daytime mood is highest in the youngest age group (4-5.5 year-olds), which might reflect the immaturity of emotional regulation processes.

\section{Correlational study}

- Findings are contradictory regarding the relationship of emotional functioning during awake and sleeping state: the ratio of dreams affecting daytime mood was positively associated with the effectiveness of emotional processing, yet at the same time showed a significant positive correlation with emotional and behavioral problems. These results also show that the effect of dreams on daytime mood might be an important index of emotional regulation, but to clear up the nature of the relationship we need further studies.

- In line with previous results and supporting the saliency hypothesis of dreaming, dream recall frequency was elevated for children with more emotional problems (SDQ).

- Those children who exhibited more emotional problems (SDQ) also reported more negatively toned dreams, which provides support for the neurocognitive theory of dreaming by Levine \& Nielsen.

\subsection{Overall discussion and limitations}

Overall, our data suggest that dream quality and the dream's effect on daytime mood are associated with children's difficulties in daytime emotional behavior. This supports psychological models of dreaming that assume a role of dreams in emotional regulation, and more specifically provides partial support for the plausibility of Levin and Nielsen's neurocognitive theory in a developmental context. Unfortunately, we did not find any connection between emotions in the dreams and waking emotional functioning, which is why we appreciate these results as partial support. Further studies exploring this field are needed. It is important to mention that self-reporting of emotions by young children could be prone to bias, so we consider it essential for further studies of this area to include a control for emotions by independent coders.

Another issue of this study is that in spite of the efforts to provide specific hypotheses, it is still an explorative study in nature performing a relatively large number of correlational analyses. Traditionally, in case of multiple comparisons correction for false positive are used, however with smaller sample sizes the use of correction formula is problematic because it might eliminate valid statistical findings already established and given that dream research is a field that is still at a descriptive stage, it could stifle the explo- 
ration of new, unexpected findings (Domhoff \& Schneider, 2015). Instead of correction formulas some authors advocate follow up and replication studies, which also gives a good reason for further investigation.

\section{References}

Adolphs, R., Tranel, D., Damasio, H., \& Damasio, A. (1995). Fear and the human amygdala. Journal of Neuroscience, 15(9), 5879-5891.

Bauer, D.H. (1976). An Exploratory Study of Developmental Changes in Children's Fears. Journal of Child Psychology and Psychiatry, 17(1), 69-74.

Birkás, E., Lakatos, K., Tóth, I., \& Gervai, J. (2008). Gyermekkori viselkedési problémák lehetőségeinek felismerése rövid kérdőívekkel I: A Strength and Difficulties kérdőív magyar változata [Identifying the possibilities of childhood behavioral problems with short questionnaires I: the Hungarian version of the Strength and Difficulties Questionnaire]. Psychiatria Hungarica, 23(5), 358-365.

Bódizs, R., Simor, P., Csóka, S., Bérdi, M., \& Kopp, M.S. (2008). Dreaming and health promotion: A theoretical proposal and some epidemiological establishments. European Journal of Mental Health, 3(1), 35-62.

Brand, S., Beck, J., Kalak, N., Gerber, M., Kirov, R., Pühse, U., et al. (2011). Dream recall and its relationship to sleep, perceived stress, and creativity among adolescents. The Journal of Adolescent Health, 49(5), 525-531.

Braun, A. (1997). Regional cerebral blood flow throughout the sleep-wake cycle. An H2(15) O PET study. Brain, 120(7), 1173-1197.

Bremner, J.D., Vermetten, E., Vythilingam, M., Afzal, N., Schmahl, C., Elzinga, B., \& Charney, D.S. (2004). Neural correlates of the classic color and emotional stroop in women with abuse-related posttraumatic stress disorder. Biological Psychiatry, 55(6), 612-620.

Burnham, M.M., \& Conte, C. (2010). Developmental perspective dreaming across the lifespan and what this tells us. International Review of Neurobiology, 92, 47-68.

Camras, L.A., \& Allison, K. (1985). Children's understanding of emotional facial expressions and verbal labels. Journal of Nonverbal Behavior, 9(2), 84-94.

Cartwright, R. (1991). Dreams that work: The relation of dream incorporation to adaptation to stressful events. Dreaming, 1(1), 3-9.

Cartwright, R. (2011). Dreaming as a mood regulation system. In M.H. Kryger, W.C. Dement, \& T. Roth (Eds.), Principles and practice of sleep medicine (5th ed.) (620-627). St. Louis: Elsevier, Saunders

Cartwright, R., Agargun, M.Y., Kirkby, J., \& Friedman, J.K. (2006). Relation of dreams to waking concerns. Psychiatry Research, 141(3), 261-270.

Cartwright, R., Luten, A., Young, M., Mercer, P., \& Bears, M. (1998). Role of REM sleep and dream affect in overnight mood regulation: a study of normal volunteers. Psychiatry Research, 81(1), 1-8.

Cohen, D.B. (1974). Presleep mood and dream recall. Journal of Abnormal Psychology, 83(1), 45-51.

Colace, C. (1998). Sulla valutazione della credibilità dei sogni raccontati dai bambini: uno studio preliminare. Psichiatria Dell Infanzia E Dell Adolescenza, 65, 5-18.

Colace, C. (2010). Children's dreams: From Freud's observations to modern dream research (1st ed.). London: Karnac Books Ltd. 
Compton, R.J., Banich, M.T., Mohanty, A., Milham, M.P., Herrington, J., Miller, G.A, et al. (2003). Paying attention to emotion: an fMRI investigation of cognitive and emotional stroop tasks. Cognitive, Affective \& Behavioral Neuroscience, 3(2), 81-96.

Despert, L.J. (1949). Dreams in Children of Preschool Age. Psychoanalytic Study of the Child, 3, 141-180.

Domhoff, G.W., \& Schneider, A. (2015). Correcting for multiple comparisons in studies of dream content: A statistical addition to the Hall/Van de Castle coding system. Dreaming, 25(1), 59-69.

Eschenbeck, H., Kohlmann, C.W., Heim-Dreger, U., Koller D., \& Leser, M. (2004). Processing bias and anxiety in primary school children: A modified emotional Stroop colour-naming task using pictorial facial expressions. Psychology Science, 46(4), 451-465.

Etkin, A., Egner, T., Peraza, D.M., Kandel, E.R., \& Hirsch, J. (2006). Resolving emotional conflict: a role for the rostral anterior cingulate cortex in modulating activity in the amygdala. Neuron, 51(6), 871-882.

Feinstein, J.S., Adolphs, R., Damasio, A., \& Tranel, D. (2011). The human amygdala and the induction and experience of fear. Current Biology, 21(1), 34-38.

Foulkes, D. (1969). Two Stuies of Childhood Dreaming. American Journal of Orthopsychiatry, 39(4), 617-642.

Foulkes, D. (1982). Children's dreams: Longitudinal studies. John Wiley \& Sons Inc.

Foulkes, D. (1985). Dreaming: A cognitive-psychological analysis. New Jersey: L. Erlbaum Associates

Foulkes, D. (1999). Children's dreaming and the development of consciousness. Cambridge, Massachusetts: Harvard University Press

Foulkes, D., Hollifield, M., Sullivan, B., Bradley, L., \& Terry, R. (1990). REM Dreaming and Cognitive Skills at Ages 5-8: A Cross-sectional Study. International Journal of Behavioral Development, 13(4), 447-465.

Foulkes, D., Larson, J.D., Swanson, E.M., \& Rardin, M. (1969). Two Studies of Childhood Dreaming. American Journal of Orthopsychiatry, 39(4), 627-643.

Foulkes, D., \& Shepherd, J. (1971). Manual for a scoring system for children's dreams. Laramie: University of Wyoming

Foulkes, D., Sullivan, B., Kerr, N.H., \& Brown, L. (1988). Appropriateness of dream feelings to dreamed situations. Cognition \& Emotion, 2(1), 29-39.

Goodman, R. (2001). Psychometric properties of the strengths and difficulties questionnaire. Journal of the American Academy of Child and Adolescent Psychiatry, 40(11), 1337-1345.

Goodman, R., \& Scott, S. (1999). Comparing the Strengths and Difficulties Questionnaire and the Child Behavior Checklist: Is Small Beautiful? Journal of Abnormal Child Psychology, $27(1), 17-24$.

Hadwin, J.A., Donnelly, N., Richards, A., French, C.C., \& Patel, U. (2009). Childhood anxiety and attention to emotion faces in a modified stroop task. British Journal of Developmental Psychology, 27(2), 487-494.

Hall, C.S., \& Van de Castle, R.L. (1966). The content analysis of dreams. New York: AppletonCentury-Crofts

Hänsel, A., \& von Känel, R. (2008). The ventro-medial prefrontal cortex: a major link between the autonomic nervous system, regulation of emotion, and stress reactivity? BioPsychoSocial Medicine, 2, 21. doi:10.1186/1751-0759-2-21

Hartmann, E. (2010). The Underlying Emotion and the Dream: Relating Dream Imagery to the Dreamer's Underlying Emotion can Help Elucidate the Nature of Dreaming. International Review of Neurobiology, 92, 198-213. 
Heim-Dreger, U., Kohlmann, C.-W., Eschenbeck, H., \& Burkhardt, U. (2006). Attentional biases for threatening faces in children: Vigilant and avoidant processes. Emotion, 6(2), 320-325.

Honig, A.S., \& Nealis, A.L. (2012). What do young children dream about? Early Child Development and Care, 182(6), 771-795.

Jenni, O.G., \& Dahl, R.E. (2008). Sleep, cognition, and emotion: A developmental view. In C. A. Nelson \& M. Luciana (Eds.), Handbook of developmental cognitive neuroscience (2nd ed.) (807-817). Cambridge: MIT Press

Kahn, D., Pace-Schott, E., \& Hobson, J.A. (2002). Emotion and cognition: feeling and character identification in dreaming. Consciousness and Cognition, 11(1), 34-50.

Kindt, M., Bierman, D., \& Brosschot, J.F. (1997). Cognitive bias in spider fear and control children: assessment of emotional interference by a card format and a single-trial format of the stroop task. Journal of Experimental Child Psychology, 66(2), 163-179.

Kramer, M. (1993). The selective mood regulatory function of dreaming: An update and revision. In A.R. Moffitt, M. Kramer, \& R.F. Hoffmann (Eds.), The functions of dreaming. SUNY series in dream studies (139-195). State University of New York Press

Levin, R., \& Nielsen, T.A. (2007). Disturbed dreaming, posttraumatic stress disorder, and affect distress: A review and neurocognitive model. Psychological Bulletin, 133(3), 482-528.

MacLeod, C., Mathews, A., \& Tata, P. (1986). Attentional bias in emotional disorders. Journal of Abnormal Psychology, 95(1), 15-20.

Maquet, P., Péters, J., Aerts, J., Delfiore, G., Degueldre, C., Luxen, A., \& Franck, G. (1996). Functional neuroanatomy of human rapid-eye-movement sleep and dreaming. Nature, 383(6596), 163-166.

McKenna, F.P., \& Sharma, D. (2004). Reversing the emotional stroop effect reveals that it is not what it seems: The role of fast and slow components. Journal of Experimental Psychology: Learning, Memory, and Cognition, 30(2), 382-392.

Merritt, J.M., Stickgold, R., Pace-Schott, E., Williams, J., \& Hobson, J.A. (1994). Emotion profiles in the dreams of men and women. Consciousness and Cognition, 3(1), 46-60.

Nielsen, T.A., Deslauriers, D., \& Baylor, G.W. (1991). Emotions in dream and waking event reports. Dreaming, 1(4), 287-300.

Nielsen, T.A., \& Levin, R. (2007). Nightmares: A new neurocognitive model. Sleep Medicine Reviews, 11(4), 295-310.

Pagel, J.F., Vann, B.H., \& Altomare, C.A. (1995). Reported association of stress and dreaming: Community background levels and changes with disaster (Hurricane Iniki). Dreaming, 5(1), 43-50.

Piaget, J. (1976). Piaget's Theory. In B. Inhälder \& H. Chipman (Eds.), Piaget and his school (11-23). Berlin: Springer

Punamäki, R.-L. (1999). The relationship of dream content and changes in daytime mood in traumatized vs. non-traumatized children. Dreaming, 9(4), 213-233.

Punamäki, R.-L., Ali, K. J., Ismahil, K.H., \& Nuutinen, J. (2005). Trauma, dreaming, and psychological distress among Kurdish children. Dreaming, 15(3), 178-194.

Sándor, P., Szakadát, S., Kertész, K., \& Bódizs, R. (2015). Content analysis of 4 to 8 year-old children's dream reports. Frontiers in Psychology, 6(534). doi:10.3389/fpsyg.2015.00534

Sándor, P., Szakadát, S., \& Bódizs, R. (2014). Ontogeny of dreaming: a review of empirical studies. Sleep Medicine Reviews, 18(5), 435-449.

Schachter, S., \& Singer, J. (1962). Cognitive, social, and physiological determinants of emotional state. Psychological Review, 69(5), 379-399.

Schredl, M. (1999). Dream recall: Research, clinical implications and future directions. Sleep and Hypnosis, 1(2), 72-81.

Schredl, M. (2003). Effects of state and trait factors on nightmare frequency. European Archives of Psychiatry and Clinical Neuroscience, 253(5), 241-247. 
Schredl, M., \& Engelhardt, H. (2001). Dreaming and psychopathology: Dream recall and dream content of psychiatric inpatients. Sleep and Hypnosis, 3(1), 44-54.

Schredl, M., Fricke-Oerkermann, L., Mitschke, A., Wiater, A., \& Lehmkuhl, G. (2009). Longitudinal study of nightmares in children: stability and effect of emotional symptoms. Child Psychiatry \& Human Development, 40(3), 439-449.

Schredl, M., \& Montasser, A. (1996). Dream recall: State or trait variable? Part II: State factors, investigations and final conclusions. Imagination, Cognition and Personality, 16(3), 239-261.

Schredl, M., \& Sartorius, H. (2010). Dream recall and dream content in children with attention deficit/hyperactivity disorder. Child Psychiatry and Human Development, 41(2), 230-238.

Schredl, M., Schafer, G., Weber, B., \& Heuser, I. (1998). Dreaming and insomnia: Dream recall and dream content of patients with insomnia. Journal of Sleep Research, 7(3), 191-198.

Simor, P., Pajkossy, P., Horváth, K., \& Bódizs, R. (2012). Impaired executive functions in subjects with frequent nightmares as reflected by performance in different neuropsychological tasks. Brain and Cognition, 78(3), 274-283.

Steklis, H., \& Kling, A. (1985). Neurobiology of affiliative behavior innonhuman primates. In M. Reite, \& T. Field (Eds.), The Psychobiology of Attachment and Separation (93-134). New York: Academic Press

Urry, H.L., van Reekum, C.M., Johnstone, T., Kalin, N.H., Thurow, M.E., Schaefer, H.S., et al. (2006). Amygdala and ventromedial prefrontal cortex are inversely coupled during regulation of negative affect and predict the diurnal pattern of cortisol secretion among older adults. The Journal of Neuroscience : The Official Journal of the Society for Neuroscience, 26(16), 4415-4425.

Walker, M.P., \& van der Helm, E. (2009). Overnight therapy? The role of sleep in emotional brain processing. Psychological Bulletin, 135(5), 731-748.

Weisz, R., \& Foulkes, D. (1970). Home and laboratory dreams collected under uniform sampling conditions. Psychophysiology, 6(5), 588-596.

Whalen, P.J., Bush, G., McNally, R.J., Wilhelm, S., McInerney, S.C., Jenike, M.A., \& Rauch, S.L. (1998). The emotional counting stroop paradigm: a functional magnetic resonance imaging probe of the anterior cingulate affective division. Biological Psychiatry, 44(12), 1219-1228.

Yoo, S.-S.S., Gujar, N., Hu, P., Jolesz, F.A., \& Walker, M.P. (2007). The human emotional brain without sleep - a prefrontal amygdala disconnect. Current Biology, 17(20), 877-878.

\section{Acknowledgments}

The work was supported by the 2010 Research Grant of the BIAL Foundation (55/10) and the Hungarian National Scientific Research Fund (OTKA-K105367).

\section{Division of labor}

The authors took part in the following processes in connection with the preparation of the present article: Piroska Sándor: study design and organization, data collection, data analysis, the preparation of all sections of the present article. Sára Szakadát: study organization, data collection, data analysis, final review of the article. Róbert Bódizs: study design and supervision, article concept, final review of the article. 


\title{
Conflict of interest
}

The authors have no conflict of interest to declare.

\section{Álmodás és érzelemszabályozás fejlódése - egy neurokognitív álomelmélet gyermekkori álmok tükrében}

\author{
SÁNDOR PIROSKA - SZAKADÁT SÁRA - BÓDIZS RÓBERT
}

Elméleti háttér: Annak ellenére, hogy számos kutatás világít rá a REM alvás neurális fejlődésben betöltött szerepére, a fejlődéstani álomkutatás mindmáig elhanyagolt terület a felnőttkori álmodás vizsgálatához képest. Felnőtt adatok bizonyítják, hogy a REM alvás és az álmodás fontos szerepet tölt be az emocionális élményfeldolgozásban, érzelmi emlékek konszolidációjában és a negatív ingerekre adott érzelmi reakciók szabályozásában. Az egyik legismertebb elmélet, amely álmodás egyik funkcióját az érzelmi regulációban látja, a Levin és Nielsen-féle neurokognitív álomelmélet. Ezek az álomelméletek azonban nem jelennek meg fejlődéstani kontextusban.

Célok: Célunk a neurokognitív álomelmélet tesztelése az éber érzelemszabályozás, valamint érzelmi-viselkedéses problémák és a gyerekálmok érzelmi aspektusai közötti kapcsolatok feltárása által.

Módszer: 404 és 8 év közötti gyerek 349 álmát gyújtöttük és elemeztük. Az álmok érzelmi aspektusainak (álombeli érzelmek, érzelmi álomminőség, az álmok hatása a nappali hangulatra) feltárásához a gyerekek saját értékeléseire támaszkodtunk. Az éber érzelmi feldolgozást az Érzelmi Stroop teszt gyerek változatával mértük, a viselkedéses-érzelmi problémák mértékét pedig a szülő által kitöltött Képességek és Nehézségek Kérdőív (SDQ) magyar változatával.

Eredmények: A negatív álomérzelmek és az álmok nappali hangulatra gyakorolt hatása összefügg az SDQ-val mért érzelmi megküzdési nehézségekkel ( $\tau=0,25, p=0,031 ; \tau=0,24$, $\mathrm{p}=0,041)$. Valamint a több érzelmi problémát mutató gyerekek több álomról számoltak be $(\tau=0,32, p=0,004)$. Nem várt módon az álomérzelmek nem mutattak kapcsolatot az érzelmi fejlődés éber tesztjeivel.

Konklúzió: Az eredmények alátámasztják azokat a pszichológiai álom-modelleket, amelyek az álmodásnak különleges szerepet tulajdonítanak az érzelemszabályozásban és részben igazolják a Nielsen és Levin-féle neurokognitív elméletet fejlődéstani kontextusban. További kutatások szükségesek azonban annak feltárására, hogy pontosan hogyan függ össze a nappali érzelmi múködés a REM alvással és álmodással gyerekeknél, különös tekintettel a fejlődési aspektusokra.

Kulcsszavak: gyerekek álmai, érzelmi fejlődés, Érzelmi Stroop Teszt, álombeli érzelmek, neurokognitív álomelmélet 